\title{
Can secondary species maintain a primary role? Consistent inter-regional effects of understory algae on diversity
}

\author{
Camilla Bertolini ${ }^{1}$ (iD
}

Received: 3 September 2017 / Revised: 26 January 2018 / Accepted: 22 February 2018 / Published online: 16 March 2018

(C) The Author(s) 2018

\begin{abstract}
Loss of habitat is a global threat to biodiversity. Habitat-forming species in particular are shifting their distribution at local and regional scales, changing habitat aspect globally. In temperate intertidal rocky shores, this poleward shift of canopy-forming seaweeds is leading to a shift to mat- or turf-dominated communities. These changes and their consequences are poorly understood and can vary globally. Most studies, however, have focused on local and regional processes. Using rocky low intertidal algal-dominated systems, this study aims to understand the independent role of a rich understory vegetation layer formed by cespitose algae as community drivers. Moreover, the study aimed to understand whether the observed patterns can be consistent over spatial regions, thus three distinct regional zones of the North Atlantic (Eastern shores of Nova Scotia, Canada; the PoitouCharentes coast, France; the Eastern shores of Northern Ireland, UK) were sampled as part of this study. From surveys, results showed that in the intertidal zone with low desiccation potential, canopies generally do not drive understory cespitose species richness or distribution. Cespitose algae on the other hand positively influenced richness in all regions. Community composition was also influenced by cespitose algal species, which increased the number of mobile epifauna species, while decreasing the number of encrusting epifauna species. This has wide implications: (i) understory species that are often overlooked may play a primary role as habitat formers; (ii) understory species may help maintain biodiversity in a changing world where primary species distribution is shifting.
\end{abstract}

Keywords Ecosystem engineers $\cdot$ Habitat formers $\cdot$ Inter-regional $\cdot$ Canopy $\cdot$ Understory $\cdot$ Rocky shore

\section{Introduction}

Loss of habitat is a global threat to biodiversity (Pimm and Lawton 1978; Airoldi and Beck 2007). Habitat loss can include the direct loss of foundation species (sensu Dayton 1972; Altieri and van de Koppel 2014) and habitat-formers, which ultimately leads to losses of the three-dimensional habitat complexity of many systems (Turner et al. 1999; Ellison et al. 2005; Airoldi et al. 2008). Local and global stressors are leading to changes in community of habitat-forming species (Cole et al. 2016; Dijkstra et al. 2017).

In temperate intertidal habitats globally, climate-driven shifts from canopy-dominated algal communities to smaller

Communicated by B. Beszteri

Camilla Bertolini

camilla.bertolini@nioz.nl

1 NIOZ, Royal Netherlands Institute for Sea Research, Korringaweg 7, 4401 NT Yerseke, Netherlands mat- and turf-forming dominated communities are observed (Strain et al. 2014). Canopy-forming species are considered engineers and can increase local species biodiversity by means of facilitation (Bruno et al. 2003; Gouhier et al. 2011), modifying light penetration and availability, providing refuge from stressors such as desiccation, and also providing an important food source to many species (Valdivia et al. 2012; Crowe et al. 2013; Watt and Scrosati 2013; Migné et al. 2014). Following the loss of canopies, different studies observed a range of responses, with great variation observed across European shores (e.g. Bertocci et al. 2010; Bulleri et al. 2012; Crowe et al. 2013). Despite this high variability, trends showed overall negative effects on community stability and species diversity, particularly on southern shores (Valdivia et al. 2012; Bulleri et al. 2012; Crowe et al. 2013).

Canopy systems are often layered and under the primary canopy other species can form shrub-like habitats, which can have ecosystem structuring effects (Bustamante et al. 2014; Ballantyne and Pickering 2015). With the primary canopies under threat from anthropogenic disturbances (Wahl et al. 
2015; Wernberg et al. 2016), it is predicted that shorelines will be increasingly dominated by sub-canopy cespitose and turf forming species (Jenkins et al. 2004; Airoldi et al. 2008; Benedetti-Cecchi et al. 2012; Smith et al. 2014). The role of this secondary canopy formed by assemblages of cespitose forming algae (mostly tufty cespitose red algae and coralline species) is still poorly understood (Schaal et al. 2016). These cespitose understory species could have a positive effect on biodiversity: they form complex habitats which could aid other species attachment to the substrate, without impairing light penetration or causing whiplash effects due to their shorter form. The cespitose form can also trap sediment in rocky shores allowing detritivores to thrive, changing trophic levels of the dominant shore invertebrates (Dijkstra et al. 2017). Moreover, the great space occupancy of these species could lead to the exclusion of encrusting taxa, changing shore community dynamics (Bustamante et al. 2014). In this scenario of global changes, it is therefore essential to consider whether species which will become dominant can offset diversity losses caused by the loss of primary engineering species (Dijkstra et al. 2017; Ramus et al. 2017).

The region-specific nature of most studies does not allow for global generalisation (Johnson et al. 2003; Watt and Scrosati 2013). The nature of canopy and cespitose/turf-forming species can be highly variable (Crowe et al. 2013) and follows variable definitions (Connell et al. 2014). There are known differences in processes acting in rocky shores communities in the North East and North West Atlantic, with the former being dominated by grazing patterns and the latter by competition and predation, although the resulting communities are found to be of a similar nature (Jenkins et al. 2008). There is therefore a need to compare patterns across multiple regions to assess whether layering effects on biodiversity are important.

The aim of this study is to understand the role of the secondary canopy formed by cespitose algae in shaping rocky shore biodiversity. The hypotheses tested within this study were that (1) understory, cespitose species occur independently of primary canopy in low stress environments and (2) established understory can increase local biodiversity independently of the primary species. These hypotheses were addressed in three distinct Atlantic regions to understand whether or not effects could be universal.

\section{Material and methods}

The role of secondary canopies was studied from observations in Nova Scotia (Canada, NW Atlantic), Poitou-Charentes coast (France, NE Atlantic), and Northern Ireland (UK, Irish Sea) (Fig. 1). Data from Nova Scotia were from a published dataset of a large-scale mensurative study conducted to assess the effects of primary canopy on different intertidal areas (Watt and Scrosati 2013, Watt and Scrosati 2013). From the dataset, only data relative to the low intertidal zone, selected as the area containing mostly Fucus serratus and exposed during spring tides, were selected to understand effects of secondary engineers in low-stress environments (low-stress sites as defined in Watt and Scrosati 2013; Watt and Scrosati 2013). Sampling methods as described in the paper were then replicated in the other two regions, and sites were chosen in relatively similar sheltered conditions (based on personal observations, shore composition, personal communications Dr. Sauriau, Dr. O'Connor). Briefly, $25 \times 25 \mathrm{~cm}$ quadrats were randomly sampled in the low intertidal zone at each site (Nova Scotia: $N=389$, Poitou-Charentes: $N=139$, Northern Ireland: $N=93$ ). The percentage cover of primary canopy, if present, was recorded; then the primary canopy was moved aside and the percentage cover of each of the understory species was recorded together with any other species present. Four sites were sampled in Nova Scotia (Godie point, 45.6115000, -60.8198333, Taylors head 44.786729, 62.544669, Torbay 45.199612, -61.365825 , Unnamed site northeast of Torbay $45.1851667,-61.3363333)$, two in the Poitou-Charentes (LeGrouin 46.230662, - 1.414667, Sabia 46.041986, - 1.389636) and three in Northern Ireland (Blackhead 54.766694, - 5.688425, Donaghadee 54.639762, -5.528202 , Kearney 54.389138, -5.459597 ) (Fig. 1) .

\section{Determination of canopies and understory species}

Cespitose understory species were defined as those algae species not forming canopies, being $>1 \mathrm{~cm}$ tall and having a branching form (e.g., not sheet like, like Ulva spp., Table 1).

The effects of canopy on the number and percentage cover of specific understory algae species were only identified for Northern Ireland and France for consistency of data collection and thus species present in Nova Scotia have been only listed (Table 1). Overall percentage cover of canopy and understorey was identified for all regions (Fig. 2a, b).

Canopy effects on total number of understorey algae were analysed using a linear mixed model (package lme4), with canopy cover (fixed factor, continuous variable), region (fixed factor, 2 levels) and their interaction, and site (random factor nested within region, 5 levels). Overall $p$ values of the fixed and random factor respectively were calculated with the functions anova (type III ANOVA using Sattherthwaite approximation for degrees of freedom) and rand in the package lmerTest.

Canopy effects on understory algae species were analysed separately in each region using constrained ordination analysis (rda in package vegan).

\section{Determination of faunal communities}

For each quadrat, total faunal species richness was determined as the total number of faunal taxa (identified to lowest possible taxonomic level) found therein. To understand how cover of 


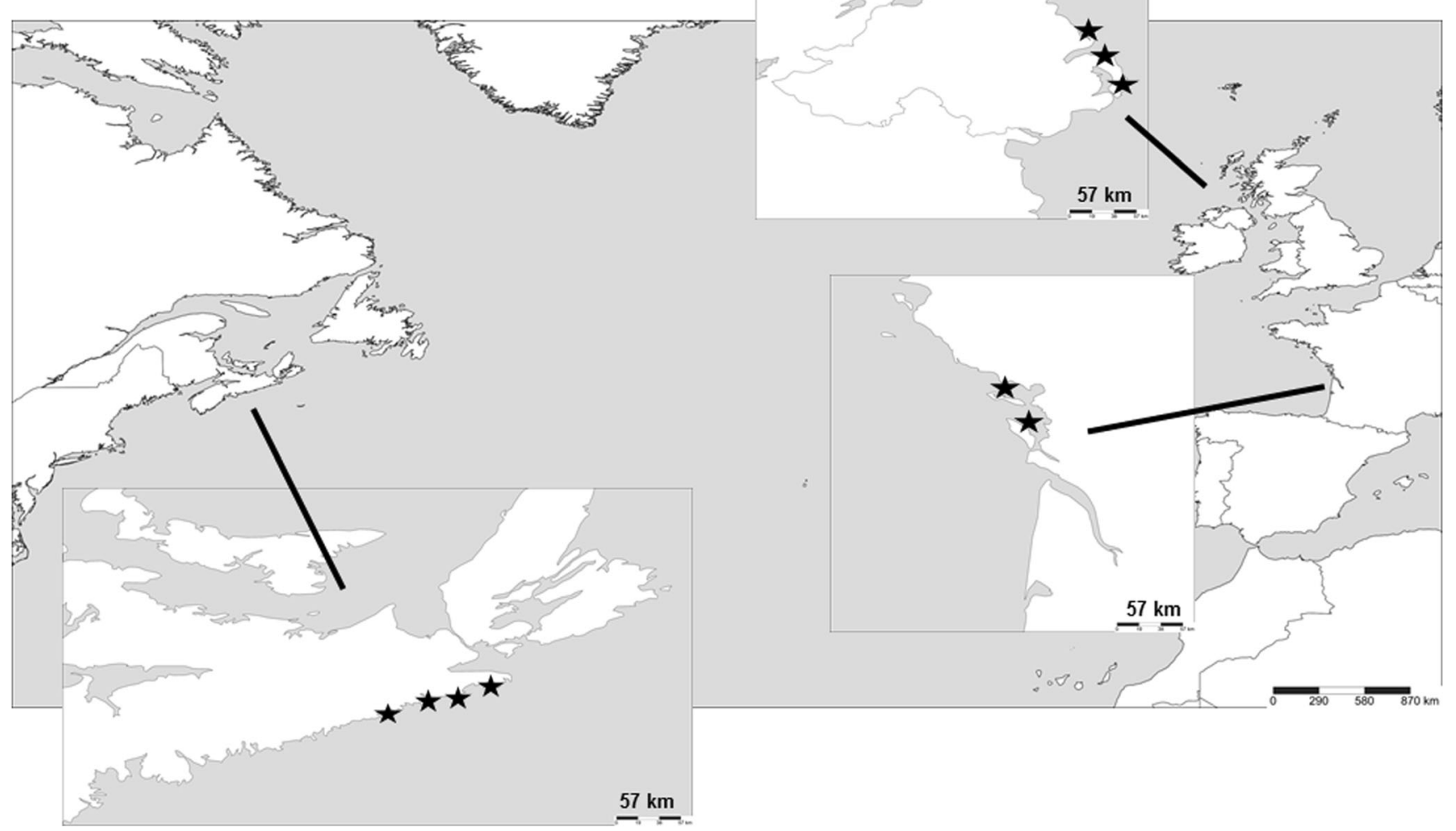

Fig. 1 Map showing position of regions and sites (black stars) within each of the three regions

canopy and cespitose algae affected associated taxon composition, fauna was separated into encrusting epifauna, mobile epifauna and infauna taxa (Table 2). Infauna taxa (Table 2) were identified as those species which normally exhibit burrowing behavior, and, despite the lack of conspicuous sediment at our sites, were observed associated with the seaweeds.

For overall species richness and encrusting epifauna species, general linear models were used, while for mobile epifauna and infauna richness, generalised linear models with
Poisson distribution were used. The initial model included percentage cover of cespitose algae, percentage cover of canopy, region, and all possible interactions, and was then reduced to an optimal model using backwards selection. The model fit was tested by testing the normality of residuals using Shapiro-test and by visualising fitted values vs residuals. A Type III Anova table was produced following the linear model to obtain overall $F$ values and $p$ values. Post hoc based on Tukey adjusted differences in estimated marginal means were used when region had significant effects.

Table 1 List of canopy and cespitose algae in Canada, France, and Ireland. Species are listed in alphabetical order

\begin{tabular}{|c|c|c|}
\hline Region & Canopy species & Cespitose species \\
\hline Canada & $\begin{array}{l}\text { Ascophyllum nodosum } \\
\text { Fucus distichus evanescens } \\
\text { Fucus serratus } \\
\text { Fucus vesiculosus }\end{array}$ & $\begin{array}{l}\text { Ceramium spp., Chondrus crispus, Cladophora spp., Corallina officinalis, Dumontia contorta, } \\
\text { Mastocarpus stellatus, Osmundea pinnatifida }\end{array}$ \\
\hline France & Fucus serratus & $\begin{array}{l}\text { Bifurcaria bifurcata, Calliblepharis jubata, Ceramium spp., Chondrus crispus, } \\
\text { Chordaria flagelliformis, Corallina spp., Dumontia contorta Furcellaria lumbricalis, } \\
\text { Gracilaria verrucosa, Gelidium spinosum, Lomentaria articulata, Osmundea pinnatifida }\end{array}$ \\
\hline Ireland & Fucus serratus & $\begin{array}{l}\text { Ceramium spp., Chondrus crispus, Corallina officinalis } \\
\text { Laurencia obtusa, Lomentaria articulata, Mastocarpus stellatus, } \\
\text { Osmundea pinnatifida, Plumaria elegans }\end{array}$ \\
\hline
\end{tabular}


Fig. 2 Histograms showing frequency of occurrence (count) of percentage cover of a canopy and $\mathbf{b}$ cespitose understory species in quadrats in the three different regions

Table 2 List of species in each of the three modes of living. Species are listed by genus or higher taxonomical order

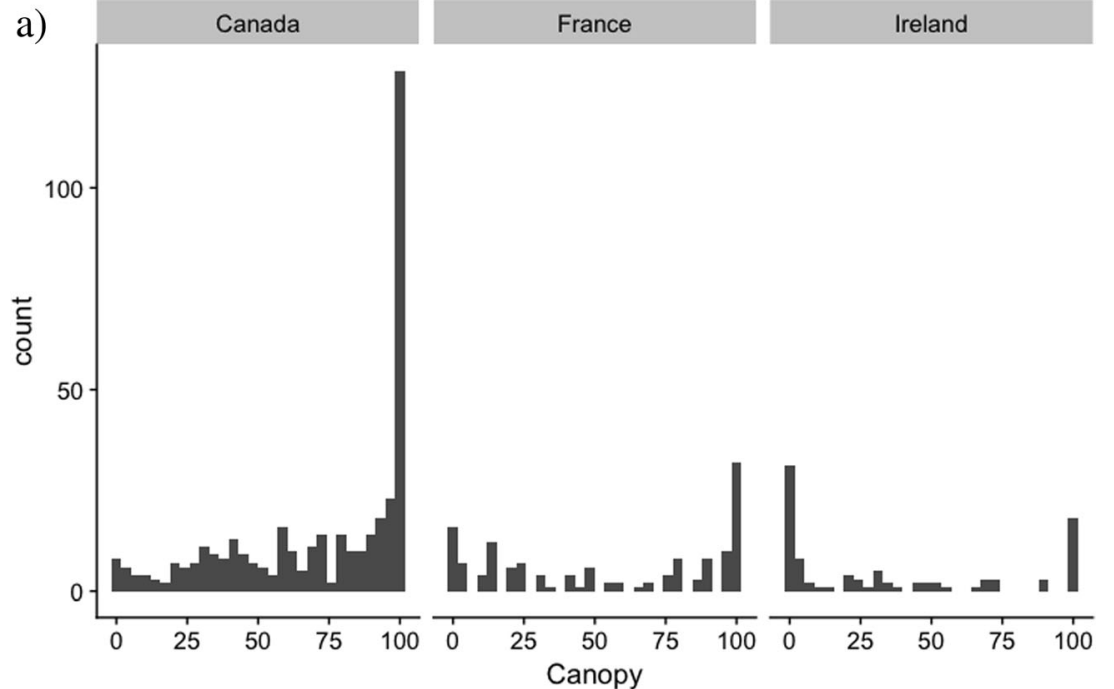

b)

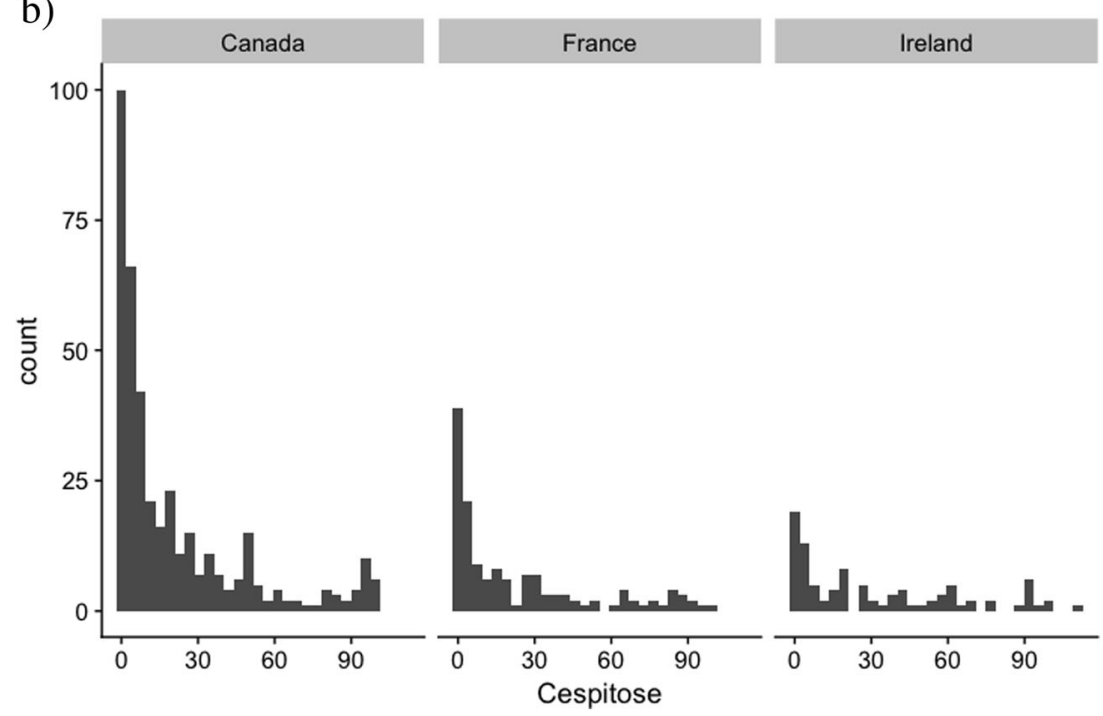

\section{Mode of living Class/family/genus list}

Encrusting epifauna

Mobile epifauna

Actinia, Alcyonidium, Amphilectus, Anomia, Balanus, Bryozoa, Chiton, Clava, Crassostrea, Demospongiae, Disporella, Dynamena, Elachista, Electra, Flustrellidae, Halicondria, Halisarca, Helcion, Hydroids, Hydroides, Leucosolemia, Membranipora, Modiolus, Mytilus, Obelia, Patella, Plumaria, Pomatoceros, Pseudosuberites, Sabellaria, Sagartia, Semibalanus, Spirobis, Sycon, Testudinalia, Tonicella, Umbonula, Urticina

Anurida, Arachnidae, Asterias, Astyris, Bittium, Buccinum, Cancer, Carcinus, Clibanarius, Echinogammarus, Eulalia viridis, Gammarus, Gibbula, Harmotoe, Hinia, Hydrobiidae, Idotea, Jaera, Lacuna, Leptasterias, Littorina, Margarites, Nucella, Ocenebra, Ophipolis, Ophiuridae, Palaemon, Pagurus, Pisa, Rissoa, Strongylocentrosus, Tricolia, Turritella, Urosalpix, Xanto

Infauna
Abra, Chironomidae, Crenella, Hiatella, Lanice, Nematoda, Nemertea, Nereis, Nerophis, Nucula, Oligochaeta, Platyhelmintes, Terebellidae 


\section{Results}

\section{Canopy and understory species}

There was an interaction between canopy cover and region on total number of understorey algae species, with lower richness observed in Northern Ireland with increasing canopy cover $\left(F_{1,209}=8.6, p<0.01\right.$, Fig. 3$)$. Canopy cover also had an overall effect $\left(F_{1,209}=4.7, p<0.05\right)$; however, there was not an overall effect of region $(p>0.05)$.

There were no effects of canopy cover on understory community structure (Table 1$)$ in France $(0.8 \%$ explained, $p>0.05$ ) or Northern Ireland (3\% variance explained, $p>0.05)$.

\section{Faunal richness and composition}

For the associated faunal community, the best model included all single terms and the interaction between cespitose and region. The interaction between cespitose and region $\left(F_{2,615}=3.68, p<0.05\right.$, Fig. $\left.3 a\right)$ was due to France having a stronger slope. Region has a significant effect on its own on richness $\left(F_{2615}=88.7, p<0.0001\right.$, Fig. $\left.4 \mathrm{c}\right)$. Post hoc shows Canada had significantly higher richness than both France $(p<0.001)$ and Ireland $(p<0.001)$, and France had significantly higher richness than Ireland $(p<0.001)$ (Fig. $4 c)$. Cespitose algae cover on its own also had a positive effect on richness $\left(F_{1,615}=54.34, p<0.0001\right.$, Fig. $\left.4 \mathrm{a}\right)$, and canopy cover also influenced richness $\left(F_{1,615}=8, p<0.001\right.$, Fig. $\left.4 \mathrm{~b}\right)$. For the encrusting epifauna species, the final model included all single terms and the interaction between region and cespitose algae and region and canopy algae. There was a

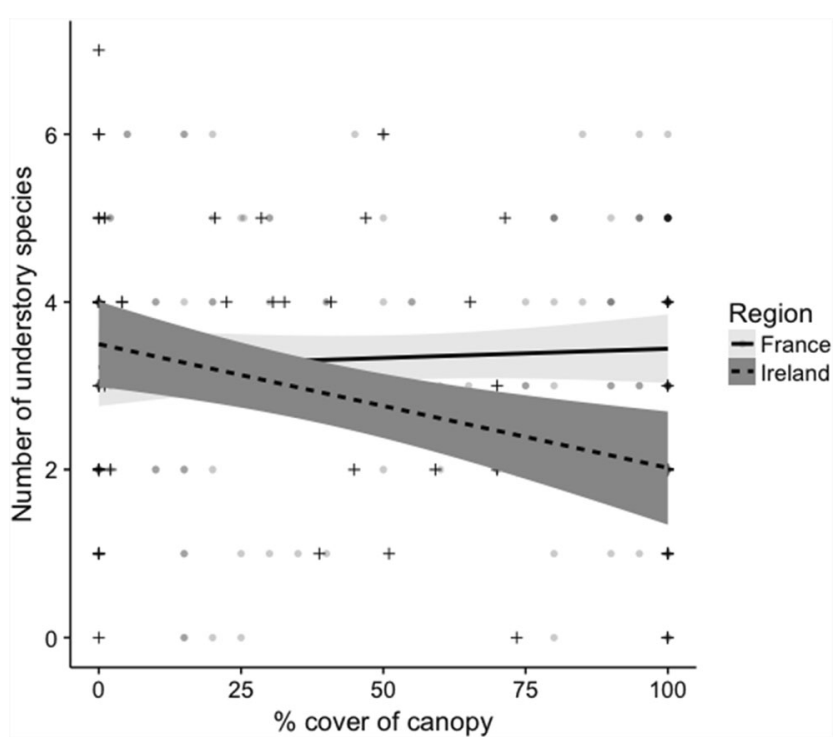

Fig. 3 Effects of canopy algae on number of understory species in France $(\bullet)$ and Northern Ireland (+) significant interaction between region and cespitose algae $\left(F_{2615}=13.9, p<0.0001\right.$, Fig. 5a) and between region and canopy algae $\left(F_{2615}=4.2, p<0.05\right.$, Fig. $\left.5 b\right)$. There was a significant effect of cespitose algae $\left(F_{2,615}=22.7\right.$, $p<0.0001$, Fig. 5a) and region $\left(F_{2,615}=4.8, p<0.001\right.$, Fig. $5 \mathrm{c})$; however, there was no effect of canopy ( $p>0.05$, Fig. $5 b)$. For number of mobile epifauna species, the final model included cespitose algae, region, and their interaction. The interaction was significant $\left(\chi_{2}=11.2, p<0.01\right)$; there was a significant effect of both cespitose algae $\left(\chi_{2}=10.2, p<0.001\right)$ and region $\left(\chi_{2}=80.1, p<0.0001\right.$, Fig. $\left.5 \mathrm{c}\right)$. For infauna species, the final model included only single terms; however, there was only a significant effect of region $\left(\chi_{2}=12.7\right.$, $p<0.01$, Fig. 5d).

\section{Discussion}

The results of this study showed that (1) understory species occur independently of primary canopy in low stress environments and (2) understory can enhance biodiversity and drive community composition independently of the primary species.

The occurrence of a rich understory species community in areas without primary canopy further highlights their potential role as engineers and drivers of changes in local faunal community. One possible reason for the slight negative effect of high canopy cover on the understory richness in Northern Ireland is that the light-barrier effect of canopy is a negative impact when light is an already limiting factor, such as in high latitude areas. Understory species relying on light for photosynthesis will be excessively smothered by lack of light, and their performance will be limited (Scrosati and Dewreede 1998; Schiel and Lilley 2007). Other putative reasons include increased sedimentation, whiplash causing changes in propagule delivery, and changes in water motion (Beermann et al. 2013). However, there was only a negative effect on overall species richness under canopy and not on species composition, suggesting all species are affected equally.

The layer of understory cespitose species was also found to have positive effects on faunal richness, which were independent of the primary canopy cover. Primary canopy had, by itself, only a weak effect on richness. Cespitose species have a complex 3D shape providing a high space-size heterogeneity and multitude of refuges for other species to exploit (Pierre and Kovalenko 2014). Habitat shape can be an important driver of faunal richness (Kelaher and Carlos Castilla 2005; Christie et al. 2007), and cespitose species can form a variety of different shapes providing a highly heterogeneous and complex habitat. These results suggest that they act as autogenic engineers, while primary canopies act mostly as allogenic engineers ameliorating stress, and thus having greater positive effects in stressful zones (Watt and Scrosati 2013). 
Fig. 4 Effects of a cover of cespitose algae, $\mathbf{b}$ cover of canopy algae and $\mathbf{c}$ region on overall species richness. Different letters indicate statistical differences $(p<0.05)$
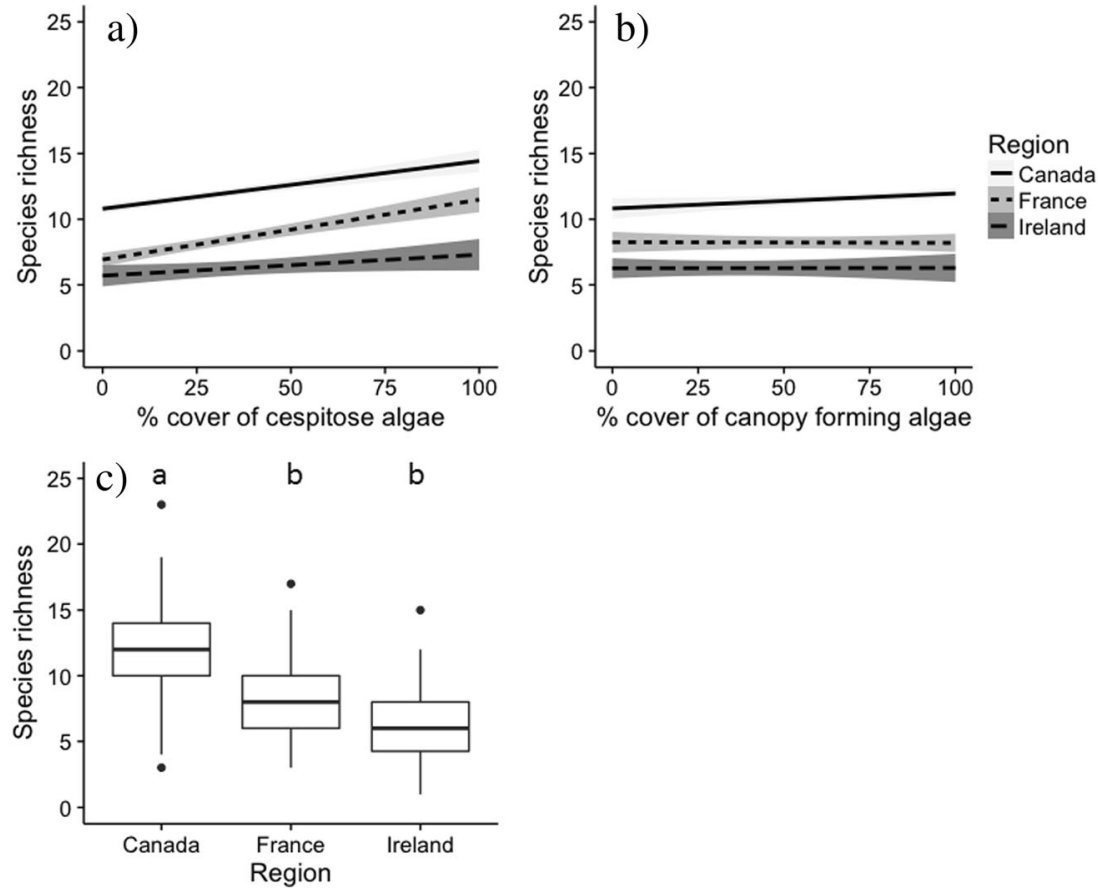

Effects of cespitose species on community composition were found, and these were independent from those of primary species, confirming the independent functional role of the secondary vegetation layer in structuring communities in these low-stress, low intertidal areas (Watt and Scrosati 2013; Bustamante et al. 2014).
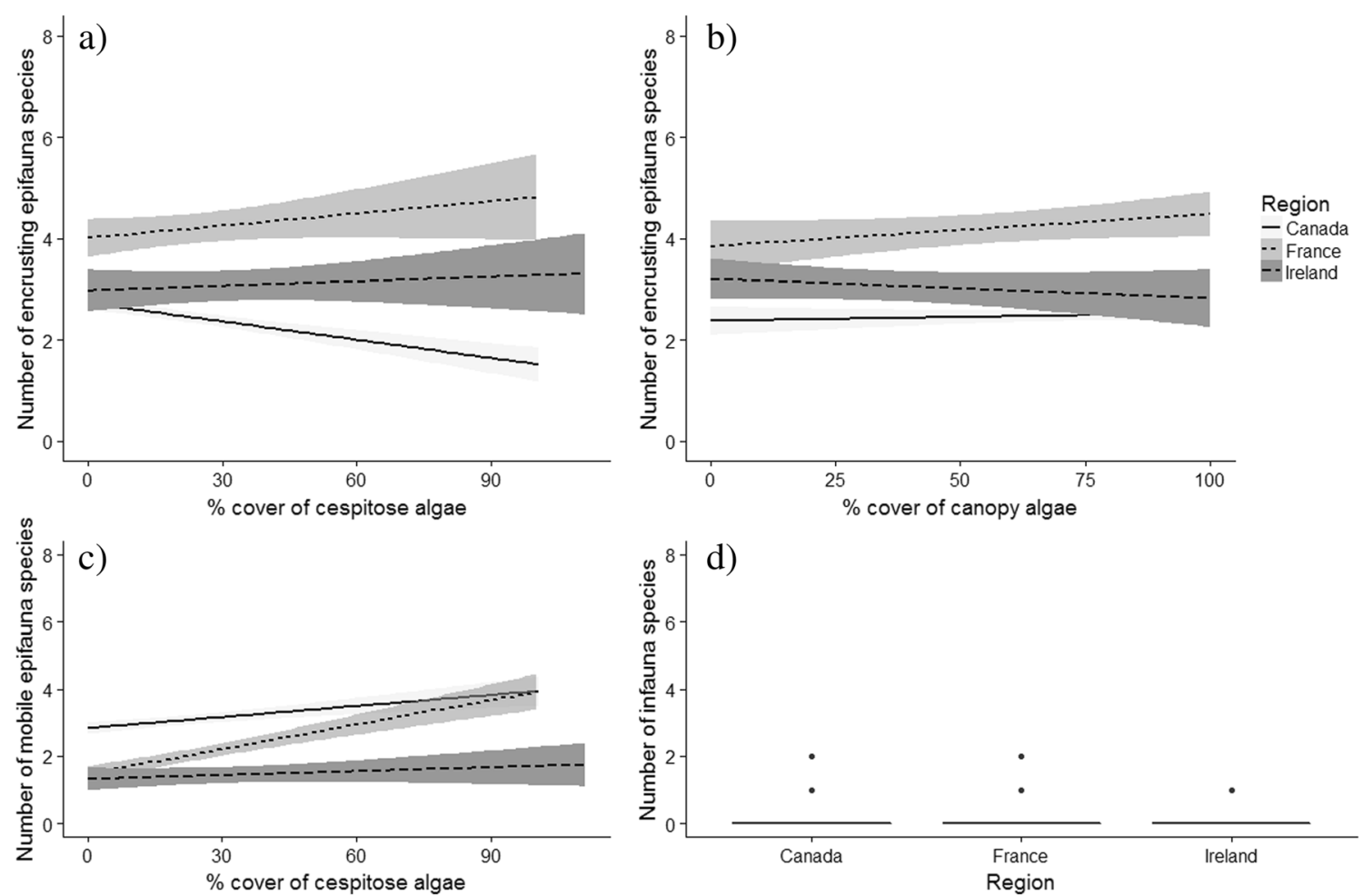

Fig. 5 Effects of a cespitose algae cover, $\mathbf{b}$ canopy algae cover on number of encrusting epifauna species, $\mathbf{c}$ cespitose algae on number of mobile epifauna species and $\mathbf{d}$ region on number of infauna species 
In the French region of the Poitou-Charentes, a stronger relationship between cespitose species and faunal richness was found. The positive effects on faunal richness in the Poitou-Charentes region were particularly true for both mobile epifauna richness and encrusting epifauna richness. One reason for this could be identified in the overall greater cespitose species richness found in this region, as more algal species should increase the richness of associated species by increasing spatial heterogeneity of the habitat and niche availability (Matias et al. 2007; Best et al. 2014; Schaal et al. 2016). However, another explanation for this could be the stronger wave action (personal observation) present at one of the sites in this region (Sabia, ile d'Oleron), suggesting that habitat formation of turf species can be even more important in exposed, more stressful, areas where organisms may have a greater need for attachment (Burrows 2012; Norderhaug et al. 2012); however, this will need further studies. As climates are changing, predictions show increased storminess and primary canopy of fucoids and laminaries shifting pole-wards (Díez et al. 2012; Smale et al. 2013); thus, it should be a priority of future studies to empirically test how understory cespitose species drive biodiversity under increased wave exposure to better understand the way stress could drive this observed pattern.

Cespitose species cover also had a mild positive effect on encrusting species in both Northern Ireland and PoitouCharentes, while they had a negative effect on encrusting species in Nova Scotia. Hypotheses on this regional inconsistency span from differences in shore exposure, and amount of sedimentation to species composition of the cespitose species community (Schaal et al. 2016). If cespitose species have a turf shape occupying the totality of the substratum, they will in turn exclude other encrusting species by competition for primary substratum. Equally, if they have a tall thallus, they may cause excessive shading (Clark et al. 2004). However, if the species produce antifouling components they will impede encrusting fauna from attaching to the algae directly (Dworjanyn et al. 2006). A mixture of cespitose species with different three-dimensional structures should therefore be the best option to ensure a great diversity of associated species (Schaal et al. 2016).

This preliminary study identified that the composition of understorey algal species, thus its complexity, is independent of primary canopy cover. This is a novel result which should drive further research on the effects of understory species complexity (Pierre and Kovalenko 2014) as secondary engineers (Angelini and Silliman 2014) and drivers of biodiversity. It has already been shown that with losses of native primary engineers their replacement with invasive species can contribute to the maintenance of biodiversity (Ramus et al. 2017): this should be further investigated globally, using models of predicted shifts to experimentally assess potential community level shifts. This was an observational study that showed similar patterns in three distinct regions of the North Atlantic. A manipulative approach with removals and addition of turf/cespitose forming species should follow to answer questions on driving mechanisms (Underwood et al. 2000).

Acknowledgements I am thankful to Prof. Ricardo Scrosati for providing me with data for the Nova Scotia region and to Dr. Pierre-Guy Sariau for the help with site choice and fieldwork help in the Poitou-Charentes region.

Funding This study received no funding.

\section{Compliance with ethical standards}

Conflict of interest The authors declare that they have no conflict of interest.

Ethical approval This article does not contain any studies with animals performed by any of the authors.

Sampling and field studies All necessary permits for sampling and observational field studies have been obtained by the authors from the competent authorities and are mentioned in the acknowledgements, if applicable.

Open Access This article is distributed under the terms of the Creative Commons Attribution 4.0 International License (http:// creativecommons.org/licenses/by/4.0/), which permits unrestricted use, distribution, and reproduction in any medium, provided you give appropriate credit to the original author(s) and the source, provide a link to the Creative Commons license, and indicate if changes were made.

\section{References}

Airoldi L, Beck MW (2007) Loss, status and trends for coastal marine habitats of Europe. Oceanogr Mar Biol 45:345-405. https://doi.org/ 10.1201/9781420050943

Airoldi L, Balata D, Beck MW (2008) The gray zone: relationships between habitat loss and marine diversity and their applications in conservation. J Exp Mar Bio Ecol 366:8-15. https://doi.org/10. 1016/j.jembe.2008.07.034

Altieri AH, van de Koppel J (2014) Foundation species in marine ecosystems. In: Bertness MD, Bruno JF, Silliman BR, Stachowicz JJ (eds) Marine community ecology and conservation. Sinauer Associates, Inc., Sunderland, pp 37-56

Angelini C, Silliman BR (2014) Secondary foundation species as drivers of trophic and functional diversity: evidence from a tree-epiphyte system. Ecology 95:185-196. https://doi.org/10.1890/13-0496.1

Ballantyne M, Pickering CM (2015) Shrub facilitation is an important driver of alpine plant community diversity and functional composition. Biodivers Conserv 24:1859-1875. https://doi.org/10.1007/ s10531-015-0910-Z

Beermann AJ, Ellrich JA, Molis M, Scrosati RA (2013) Effects of seaweed canopies and adult barnacles on barnacle recruitment: the interplay of positive and negative influences. J Exp Mar Bio Ecol 448: 162-170. https://doi.org/10.1016/j.jembe.2013.07.001 
Benedetti-Cecchi L, Tamburello L, Bulleri F et al (2012) Linking patterns and processes across scales: the application of scale-transition theory to algal dynamics on rocky shores. J Exp Biol 215:977-985. https:// doi.org/10.1242/jeb.058826

Bertocci I, Arenas F, Matias MG et al (2010) Canopy-forming species mediate the effects of disturbance on macroalgal assemblages on Portuguese rocky shores. Mar Ecol Prog Ser 414:107-116. https:// doi.org/10.3354/meps08729

Best RJ, Chaudoin AL, Bracken MES et al (2014) Plant-animal diversity relationships in a rocky intertidal system depend on invertebrate body size and algal cover. Ecology 95:1308-1322. https://doi.org/ $10.1890 / 13-1480.1$

Bruno JF, Stachowicz JJ, Bertness MD (2003) Inclusion of facilitation into ecological theory. Trends Ecol Evol 18:119-125. https://doi. org/10.1016/S0169-5347(02)00045-9

Bulleri F, Benedetti-Cecchi L, Cusson M et al (2012) Temporal stability of European rocky shore assemblages: variation across a latitudinal gradient and the role of habitat-formers. Oikos 121:1801-1809. https://doi.org/10.1111/j.1600-0706. 2011.19967.x

Burrows MT (2012) Influences of wave fetch, tidal flow and ocean colour on subtidal rocky communities. Mar Ecol Prog Ser 445:193-207. https://doi.org/10.3354/meps09422

Bustamante M, Tajadura J, Gorostiaga JM, Saiz-Salinas JI (2014) Response of rocky invertebrate diversity, structure and function to the vertical layering of vegetation. Estuar Coast Shelf Sci 147:148-155. https://doi.org/10.1016/j.ecss.2014.06.001

Christie H, Jørgensen NM, Norderhaug KM (2007) Bushy or smooth, high or low; importance of habitat architecture and vertical position for distribution of fauna on kelp. J Sea Res 58:198-208. https://doi. org/10.1016/j.seares.2007.03.006

Clark RP, Edwards MS, Foster MS (2004) Effects of shade from multiple kelp canopies on an understory algal assemblage. Mar Ecol Prog Ser 267:107-119. https://doi.org/10.3354/meps267107

Cole V, Hutchings P, Ross P (2016) Predicting biodiversity changes due to loss of bioengineers from an intertidal landscape, a case study from Sydney Harbour. Aust Zool. https://doi.org/10.7882/AZ. 2015.034

Connell SD, Foster MS, Airoldi L (2014) What are algal turfs? Towards a better description of turfs. Mar Ecol Prog Ser 495:299-307

Crowe TP, Cusson M, Bulleri F et al (2013) Large-scale variation in combined impacts of canopy loss and disturbance on community structure and ecosystem functioning. PLoS One 8: e66238. https://doi.org/10.1371/journal.pone.0066238

Dayton PK (1972) Toward an understanding of community resilience and the potential effects of enrichment to the benthos at McMurdo Sound, Antarctica. In: Parker BC (ed) Proceedings of the colloquium on conservation problems in Antarctica. Allen Press, Lawrence, Kansas. Allen Press

Díez I, Muguerza N, Santolaria A et al (2012) Seaweed assemblage changes in the eastern Cantabrian Sea and their potential relationship to climate change. Estuar Coast Shelf Sci 99:108-120. https://doi. org/10.1016/j.ecss.2011.12.027

Dijkstra JA, Harris LG, Mello K et al (2017) Invasive seaweeds transform habitat structure and increase biodiversity of associated species. J Ecol 1-11. https://doi.org/10.1111/1365-2745.12775

Dworjanyn S, de Nys R, Steinberg P (2006) Chemically mediated antifouling in the red alga Delisea pulchra. Mar Ecol Prog Ser 318:153163. https://doi.org/10.3354/meps318153

Ellison AM, Bank MS, Clinton BD et al (2005) Loss of foundation species: consequences for the structure and dynamics of forested ecosystems. Front Ecol Environ 3:479-486. https://doi.org/ 10.1890/1540-9295(2005)003[0479:LOFSCF]2.0.CO;2

Gouhier TC, Menge BA, Hacker SD (2011) Recruitment facilitation can promote coexistence and buffer population growth in metacommunities. Ecol Lett 14:1201-1210. https://doi.org/10. 1111/j.1461-0248.2011.01690.x

Jenkins SR, Norton TA, Hawkins SJ (2004) Long term effects of Ascophyllum nodosum canopy removal on mid shore community structure. J Mar Biol Assoc U K, 84(2):327-329

Jenkins SR, Murua J, Burrows MT (2008) Temporal changes in the strength of density-dependent mortality and growth in intertidal barnacles. J Anim Ecol 77:573-584. https://doi.org/10.1111/j.13652656.2008.01366.x

Johnson MP, Frost NJ, Mosley MWJ et al (2003) The area-independent effects of habitat complexity on biodiversity vary between regions. Ecol Lett 6:126-132. https://doi.org/10.1046/j.1461-0248.2003. 00404.x

Kelaher BP, Carlos Castilla J (2005) Habitat characteristics influence macrofaunal communities in coralline turf more than mesoscale coastal upwelling on the coast of Northern Chile. Estuar Coast Shelf Sci 63:155-165. https://doi.org/10.1016/j.ecss.2004.10.017

Matias MG, Underwood AJ, Coleman RA (2007) Interactions of components of habitats alter composition and variability of assemblages. $\mathrm{J}$ Anim Ecol 76:986-994. https://doi.org/10.1111/j.1365-2656.2007. 01277.x

Migné A, Golléty C, Davoult D (2014) Effect of canopy removal on a rocky shore community metabolism and structure. Mar Biol 162: 449-457. https://doi.org/10.1007/s00227-014-2592-6

Norderhaug KM, Christie H, Andersen GS, Bekkby T (2012) Does the diversity of kelp forest macrofauna increase with wave exposure? J Sea Res 69:36-42. https://doi.org/10.1016/j.seares. 2012.01.004

Pierre JI, Kovalenko KE (2014) Effect of habitat complexity attributes on species richness. Ecosphere 5:1-10

Pimm SL, Lawton JH (1978) On feeding on more than one trophic level. Nature 275:542-544

Ramus AP, Silliman BR, Thomsen MS, Long ZT (2017) An invasive foundation species enhances multifunctionality in a coastal ecosystem. Proc Natl Acad Sci 201700353. doi:https://doi.org/10. 1073/pnas.1700353114

Schaal G, Leclerc JC, Droual G et al (2016) Biodiversity and trophic structure of invertebrate assemblages associated with understorey red algae in a Laminaria digitata bed. Mar Biol Res 12:513-523. https://doi.org/10.1080/17451000.2016.1164318

Schiel DR, Lilley SA (2007) Gradients of disturbance to an algal canopy and the modification of an intertidal community. Mar Ecol Prog Ser 339:1-11

Scrosati R, Dewreede RE (1998) The impact of frond crowding on frond bleaching in the clonal intertidal alga mazzaella cornucopiae (rhodophyta, gigartinaceae) from British Columbia, Canada. J Phycol 34(2):228-232

Smale DA, Burrows MT, Moore P et al (2013) Threats and knowledge gaps for ecosystem services provided by kelp forests: a northeast Atlantic perspective. Ecol Evol 3:4016-4038. https://doi.org/10. $1002 /$ ece 3.774

Smith JR, Vogt SC, Creedon F et al (2014) The non-native turf-forming alga Caulacanthus ustulatus displaces space-occupants but increases diversity. Biol Invasions 16:2195-2208. https://doi.org/10.1007/ s10530-014-0658-5

Strain EMA, Thomson RJ, Micheli F et al (2014) Identifying the interacting roles of stressors in driving the global loss of canopyforming to mat-forming algae in marine ecosystems. Glob Chang Biol 20:3300-3312. https://doi.org/10.1111/gcb.12619

Turner SJ, Thrush SF, Hewitt JE et al (1999) Fishing impacts and the degradation or loss of habitat structure. Fish Manag Ecol 6:401-420. https://doi.org/10.1046/j.1365-2400.1999.00167.x

Underwood A, Chapman M, Connell S (2000) Observations in ecology: you can't make progress on processes without understanding the patterns. J Exp Mar Bio Ecol 250:97-115. https://doi.org/10.1016/ S0022-0981(00)00181-7 
Valdivia N, Golléty C, Migné A et al (2012) Stressed but stable: canopy loss decreased species synchrony and metabolic variability in an intertidal hard-bottom community. PLoS One 7:e36541. https:// doi.org/10.1371/journal.pone.0036541

Wahl M, Molis M, Hobday A et al (2015) The responses of brown macroalgae to environmental change from local to global scales: direct versus ecologically mediated effects. Perspect Phycol 2:11-29
Watt CA, Scrosati RA (2013) Regional consistency of intertidal elevation as a mediator of seaweed canopy effects on benthic species richness, diversity, and composition. Mar Ecol Prog Ser 491:91-99. https:// doi.org/10.3354/meps10521

Wernberg T, Arenas F, Olabarria C, Thomsen MS, Mohring M (2016)

Threats to ecosystem engineering macrophytes: climate change. In: Marine macrophytes as foundation species (ed Ólafsson E);Science Publisher/CRC Press, Boca Raton, USA. p 201-225 